\title{
Morphological Deformities in Anuran Amphibians from the Khoper River Valley in the "Privolzhskaya Lesostep" Nature Reserve and Adjacent Territories
}

\section{A.0.Svinin ${ }^{1}$, I.V. Bashinskiy², L.A. Neymark², E.A. Katsman², and V.V. Osipov³}

${ }^{1}$ Mari State University, Yoshkar-Ola, Mari El Republic

${ }^{2}$ A.N. Severtsov Institute of Ecology and Evolution (IPEE RAS), Moscow

${ }^{3}$ Privolzhskaya Lesostep' State Nature Reserve, Penza

\section{Abstract}

In summer 2016, we investigated Ostrovtsovskaya Lesostep' (Penza region, Russia) and caught more than 130 specimens belonging to 4 species of anuran amphibians. We found a symmetric case of "hyperxanthism" of the eyes (a new type of anomaly

Corresponding Author:

A.0.Svinin

ranaesc@gmail.com

Received: 23 January 2018

Accepted: 20 April 2018

Published: 3 May 2018

Publishing services provided by Knowledge $\mathrm{E}$

(c) A.O.Svinin et al. This article is distributed under the terms of the Creative Commons

Attribution License, which permits unrestricted use and redistribution provided that the original author and source are credited.

Selection and Peer-review under the responsibility of the Amphibian and Reptiles Anomalies and Pathology Conference Committee. among amphibians) in one Rana arvalis specimen, one asymmetric amely in Bombino bombina, and 21 specimens of Pelophylax ridibundus (19\% of total sample) with deformed fore and hind limbs. We define some anomalies as "Rostand's anomaly P" (in its extreme manifestations). The potential reasons of the morphological anomalies were discussed.

Keywords: amphibians, eyes hyperxanthism, amely, mandibular hypoplasy, oedema of the eyes, polydactyly, anomaly $P$.

\section{Introduction}

Anomalies are very common in amphibians and they can be caused by different reasons, such as water chemistry, $\mathrm{pH}$, parasites, inbreeding, etc. [3, 8]. The occurrence of anomalies may serve as an indicator of homeostasis of natural populations [2]. This concerns mass cases of anomalies occurring in more than $5 \%$ of individuals from representative samples. Such situations are less common, and may also be caused by various reasons [2]. However, their appearance can be an alarm signal associated with various processes within a population. In this paper, we discuss the possible reasons for numerous anomalies of amphibians and one of the first cases of mass occurrence of anomaly $\mathrm{P}$ in pure populations of marsh frogs from the Russian Federation.

\section{G OPEN ACCESS}




\section{Methods}

The study was held from June to August, 2016 in the Privolzhskaya Lesostep' nature reserve (Russian Federation). We investigated the part of the reserve called Ostrovtsovskaya Lesostep', which is located in Kolyshley district of Penza region (N52 $\left.48^{\prime} 58.4^{\prime \prime} \mathrm{E} 44^{\circ} 27^{\prime} 40.4^{\prime \prime}\right)$. The territory has forest-steppe landscapes and includes the valley of the small river Selimutka (width about 1-2 $\mathrm{m}$, depth $0.3^{-1} \mathrm{~m}$ ) and its tributary Yuzhnaya (width about 0.5-1 m, depth 0.3-0.5 m), which is surrounded by agricultural fields. The rivers are inhabited by beavers, so most of the streams are impounded. The area of ponds varies from 400 to about $8000 \mathrm{~m}^{2}$ with depths up to $2 \mathrm{~m}$. Besides the water regime, beavers affect the level of dissolved oxygen - in ponds, it amounts decrease to $1-2 \mathrm{mg} / \mathrm{I}$. In the upper parts of these rivers, there are anthropogenic dams and some old artificial reservoirs. The reserve borders with the upper flow of the Khoper River (the width here is just $10-15 \mathrm{~m}$ ). Also, there is the oxbow system of the Khoper, which consists of two main parts - "forest" and "open". The forest part consists of waterbodies in the centre of mixed forest: they never dry, have fish fauna and are used by a couple of beaver families. Open oxbows are situated on the edge of the forest and are partly surrounded by meadows, shrubs and fields: during some years, they are dry.

Sample collection and species identification were conducted using standard methods $[1,4]$, as were the registration and classification of anomalies $[5,6] .129$ individuals from 4 anuran amphibian species were caught.

\section{Results}

In Ostrovtsovskaya Lesostep, we found 6 amphibian species - Lissotriton vulgaris (Linnaeus, 1758), Bombina bombina (Linnaeus, 1761), Pelobates vespertinus (Pallas, 1771), Pelophylax ridibundus (Pallas, 1771) and Rana arvalis (Nilsson, 1842). Anomalies were found only in Anura species. The most types of anomalies were found in Pelophylax ridibundus (Table 1): the other species had only one. For Rona arvalis, a new form of anomaly was discovered (Fig. 1). We call it "hyperxanthism of the eyes". Also, we found several forms of polydactyly/polyphalangy ( $P$. ridibundus), mandibular hypoplasy ( $P$. ridibundus), asymmetric amely (B. bombina) and oedema of the eyes (larvae of Pelobates vespertinus) (Fig. 2). Anomaly $P$ was recorded for 5 individuals (3 larvae and 2 juveniles) (Fig. 3), one of the first pieces of evidence for the mass occurrence of such 
an anomaly in Russia and a unique case for pure populations of the marsh frog and population systems of R-types [3, 4].

Also we have noted the unusual behavior of spadefoot toad tadpoles. During the taking of air, they began to spin; some kept at the surface and unsuccessfully trying to dive to the bottom, making circular motions.

TABLE 1: Anomalies of $P$. ridibundus of Privolzhskaya Lesostep nature reserve ( $\mathrm{S}$ - Selimutka, BP - beaver ponds, AP - anthropogenic ponds, K - Khoper, 00 - open oxbows, FO - forest oxbows; HL - hindlimbs, FL forelimbs, the number of phalanges or fingers is shown in parentheses; I. - tadpoles; juv. - froglets; sad. - subadultus; ad. - adultus).

\begin{tabular}{|c|c|c|c|}
\hline \multirow{3}{*}{$\begin{array}{l}\text { Site } \\
00\end{array}$} & \multicolumn{3}{|c|}{ Amount of samples } \\
\hline & \multirow{2}{*}{$\begin{array}{c}\text { Total } \\
5 \text { l. }\end{array}$} & \multicolumn{2}{|c|}{ With anomalies } \\
\hline & & $1 l$. & $1 l$. \\
\hline & 50 juv. & 3 juv., & 2 juv. \\
\hline & 10 sad. & $5 \mathrm{sad}$. & 1 juv. \\
\hline & 5 od. & & $1 \mathrm{sad}$. \\
\hline & & & 3 sad. \\
\hline & & & $1 \mathrm{sad}$. \\
\hline \multirow[t]{4}{*}{ FO } & $2 I$. & $2 I$. & 1 juv. \\
\hline & 9 juv. & 6 juv. & 1 juv. \\
\hline & $1 \mathrm{sad}$ & & 3 juv. \\
\hline & 2 ad. & & 1 juv. $+2 l$. \\
\hline \multirow[t]{2}{*}{$\mathrm{BP}$} & 2 juv. & 2 juv. & 1 juv. \\
\hline & & & 1 juv. \\
\hline \multirow[t]{2}{*}{$S$} & 7 juv. & 2 juv. & 1 juv. \\
\hline & 2 sad. & & 1 juv. \\
\hline \multirow[t]{3}{*}{ K } & 8 juv. & - & - \\
\hline & $1 \mathrm{sad}$. & & \\
\hline & 3 ad. & & \\
\hline AP & 3 ad. & - & - \\
\hline Total & $\begin{array}{l}7 \text { l., } 76 \text { juv., } 14 \\
\text { sad., } 13 \text { ad. }\end{array}$ & 3 I., 13 juv., 5 sad & \\
\hline
\end{tabular}

\begin{tabular}{|c} 
Anomalies (amount of fingers) \\
anomaly P \\
polydactyly HL (6) \\
mandibular hypoplasy \\
brachydactyly + polydactyly (6) + \\
polyphalangy (2) HL \\
polydactyly (6) and polyphalangy (2) HL \\
polydactyly (6) HL + polyphalangy (5) FL \\
polydactyly HL (6) \\
polydactyly HL (7) + polyphalangy FL (5) \\
anomaly "cross" \\
anomaly P \\
polydactyly HL (6) \\
\hline polydactyly HL (6) + polyphalangy FL (5) + \\
anomaly P \\
polydactyly HL (6) \\
\hline (21 from 110, 19.1\%) \\
\hline polydactyly HL (6) + polyphalangy FL (5) \\
- \\
\hline
\end{tabular}

One of the reasons for these anomalies could be chemical pollution. In May and August, the amount of biogenic elements was measured in all types of habitat. During this period, the concentrations of phosphates increased about twice (from 6.17-7.89 to $10.11-16.74 \mathrm{mg} / \mathrm{l}$, threshold limit value (TLV) is 3.5). Obviously, this is connected with anthropogenic activities and the fertilization of nearby fields. Another important observation is the large concentrations of nitrites (up to $3.56-5.14 \mathrm{mg} / \mathrm{I}$ with TLV 3.3) and ammonia (up to $2.39-8.29 \mathrm{mg} / \mathrm{I}$ with TLV - 2). High amounts of $\mathrm{NO}_{2}{ }^{-}$, along 


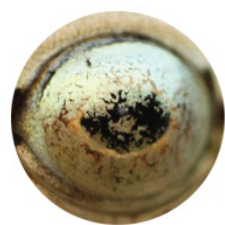

Left

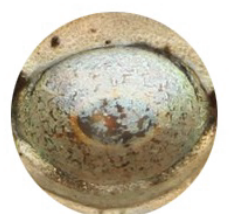

Right

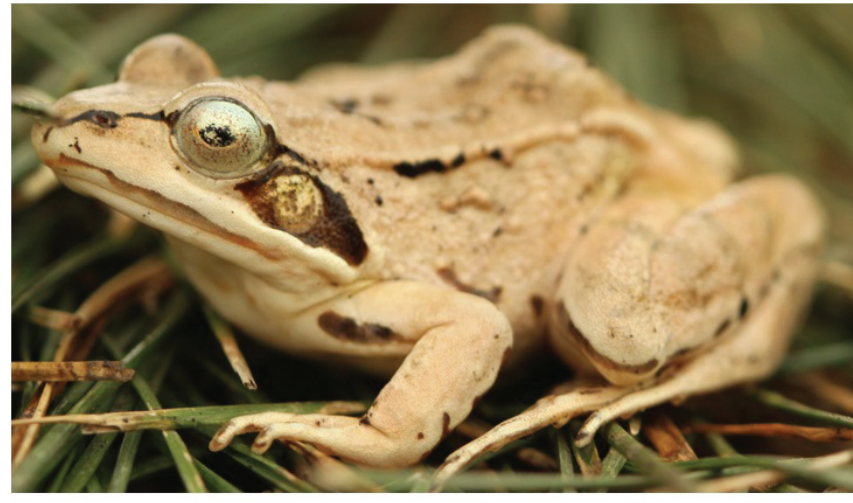

Figure 1: The hyperxanthism of the eyes in Rana arvalis is a new type of anomalies among amphibians.
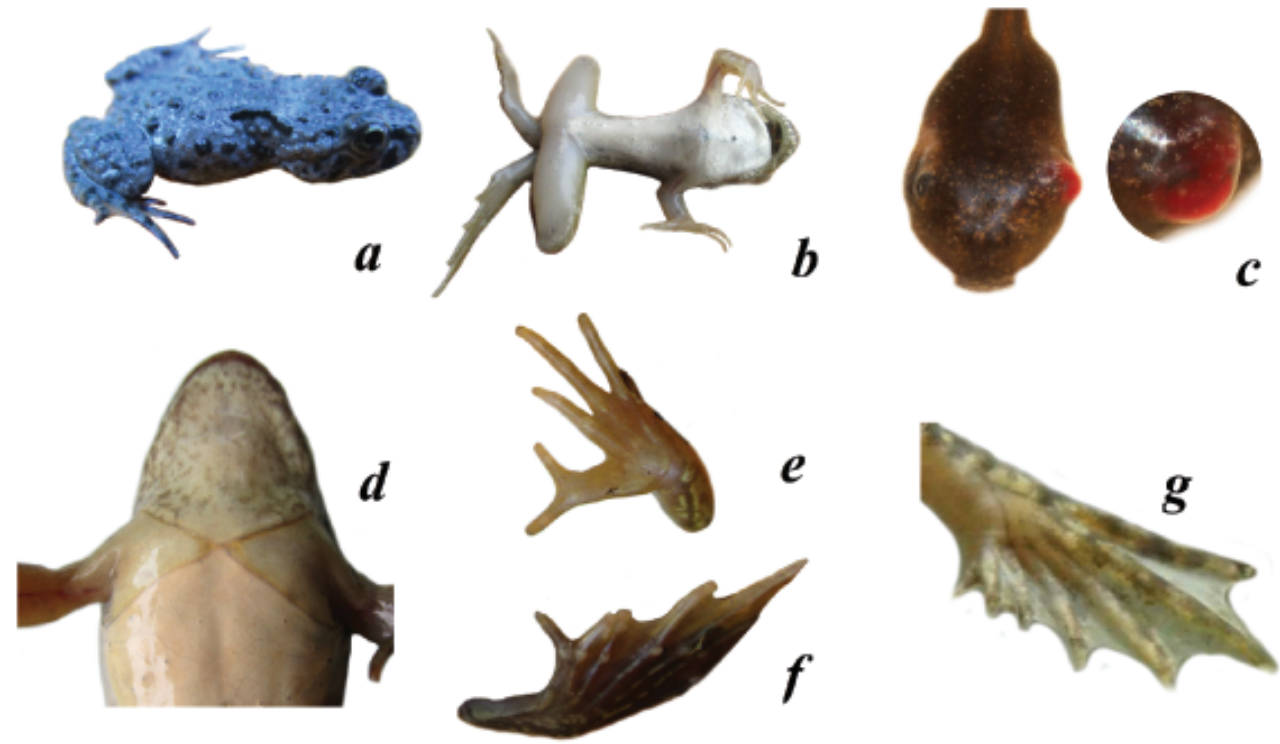

Figure 2: Anomalies of amphibians in "Privolzhskaya Lesostep" nature reserve (a - amely of Bobmina bombina; b - mandibular hypoplasy of Pelophylax ridibundus; c - oedema of the Pelobates vespertinus larvae eyes; $d$-anomaly "cross" in the Pelophylax ridibundus juveniles; and the cases of polydactyly and polyphalangy of the forelimbs (e) and hindlims ( $\mathrm{f}$ and $\mathrm{g}$ ) in Pelophylax ridibundus).

with small $\mathrm{NO}_{3}{ }^{-}$concentrations, show that a lot of organic matter does not reach final mineralization.

\section{Conclusion}

In forest-steppe landscapes, waterbodies are usually surrounded by a lot of agricultural landscapes, so anthropogenic pollution and fertilization easily drains into them. Since almost all the oxbows are framed by road embankments and dams, meltwater could not reach the main river, causing the spring floods to be too low to fill the oxbows. This situation led to the accumulation of old water and dead organic matter in such pools. 

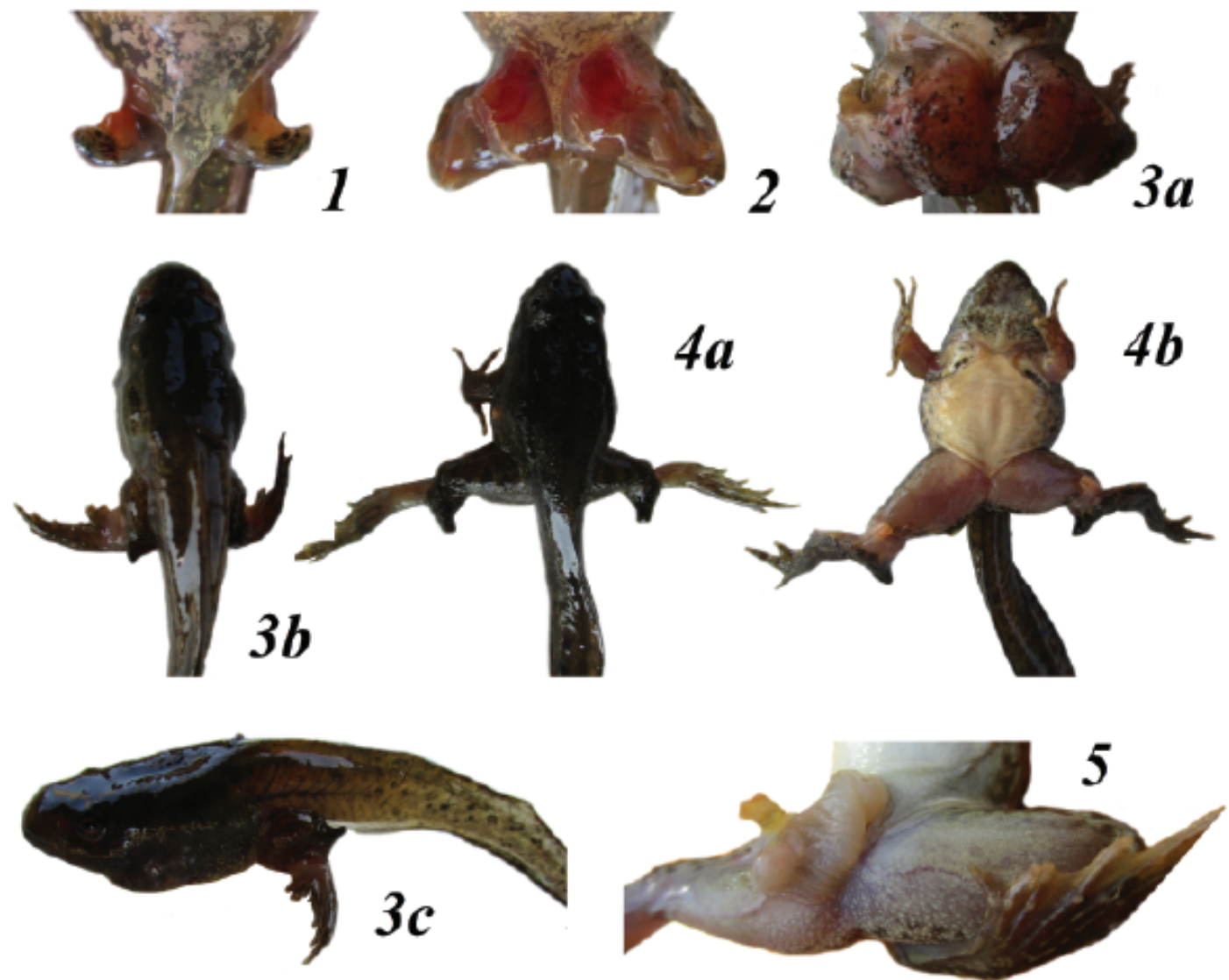

Figure 3: The cases of Rostand's anomaly P in Pelophylax ridibundus.

The aquatic habitats are also densely populated by beavers, which heavily influence the water quality.

As for anomaly $\mathrm{P}$, Jean Rostand experimentally showed that such deviations probably were caused by an infectious agent that could be teratogenic virus transmitted by fish or any components of their diet $[3,4,7]$. Perhaps the manifestation of anomaly $P$ is enhanced by the combined effect of some agrochemicals and the infectious agent that could explain its rare occurrence in Europe [4].

\section{Acknowledgements}

We would like to replace old acknowledgements with: "Authors are grateful to A. Dubois, S.N. Litvinchuk and V.L. Vershinin for valuable advices about classification of anomalies. We are thankful to A.N. Dobrolyubov for opportunity to work on the territory of nature reserve «Privolzhskaya Lesostep'». The work was supported by the 
RFBR (№ 18-04-00640 A, №16-34-00119 and № 15-29-02550) and by the grant of Mari State University (№ 2017-06b from 11.01.2017)."

\section{References}

[1] Bannikov AG, Darevsky IS, Ischchenko VG, Rustamov AK, Szczerbak NN: Guide to amphibians and reptiles of the USSR fauna. Moscow: Prosvetscheniye; 1977.

[2] Borkin LJ, Bezman-Moseyko OS, Litvinchuk SN: Evaluation of animal deformity occurrence in natural populations (an example of amphibians). Proceedings of the Zoological Institute; 2012; 4: 324-343.

[3] Dubois A: Anomalies and mutations in natural populations of the Rana "esculento" complex (Amphibia, Anura). Mitteilungen aus dem zoologischen Museum in Berlin. 1979; 51 (1): 59-87.

[4] Dubois A: Rostand's anomaly $P$ in Palaearctic green frogs (Pelophylax) and similar anomalies in amphibians. Studies on Anomalies in Natural Populations of Amphibians. Edited by K. Henle, A. Dubois. Mertensiella. 2017; 25: 49-56.

[5] Heyer WR, Donnelly MA, McDiarmid RW, Hayek L-AC, Foster MS: Measuring and monitoring biological diversity: Standard methods for amphibians. Smithsonian Institution Press; 1994: 271-273.

[6] Nekrasova OD: Classification of amphibians anomalies. Proceedings of the Ukrainian Herpetological Society; 2008; 1: 55-58.

[7] Rostand J, Darré P: Action tératogène des déjections de certains poissons sur les larves de Rana esculento. C. r. Soc. Biol. 1969; 163: 2033- 2034.

[8] Vershinin VL: Morphological anomalies of amphibians from city. Rus. J. of Ecology. 1989; 3: 58-66. 